\title{
Economic Value from Biogas Technology Application Based on Dairy Cow Farming
}

\author{
St. Aisyah R', Asriyanti Syarif
}

Agribusiness Study Program, Faculty of Agriculture, University of Muhammadiyah Makassar, Indonesia

\begin{abstract}
Article Info
Volume 8, Issue 1

Page Number: 78-82

Publication Issue :

January-February-2021
\end{abstract}

\author{
Article History \\ Accepted : 10 Jan 2021 \\ Published : 19 Jan 2021
}

\section{ABSTRACT}

This study aims to analyze the economic value of the application of biogas technology based on dairy farming. The data analysis used a quantitative method with an approach to the value of biogas waste production. The results showed that $23.575 \mathrm{~kg}$ of livestock manure in Enrekang Regency was able to produce $688,390 \mathrm{~m}^{3}$ / year of biogas production which was equivalent to 426,802 liters of kerosene so that annual savings of IDR 4.694.822.000 / year and the equivalent of $3 \mathrm{~kg}$ of Liquefied Petroleum Gas were IDR 2.111.062.667/year. Economically, it has been proven that the application of biogas installations is feasible as rural alternative energy.

Keywords : Biogas Technology, Economic Value, Dairy Farming

\section{INTRODUCTION}

Limitations and scarcity of the amount of energy derived from fuel oil that occurs cause oil prices tend to rise [1]. Utilization of biogas as an alternative energy source in addition to providing social benefits because it is environmentally friendly, but also must be able to provide economic benefits [2]. The production of biogas can control and reduce the problem of livestock waste, besides the energy produced can be used as cooking fuel. In addition, the by-product of biogas (sludge) can reduce the production costs of agricultural and livestock activities, namely as fertilizer and feed ingredients.
Costs incurred for making biogas must be able to provide economic benefits, so it is necessary to know the feasibility aspects both technically and economically [3].

Modes of production in livestock waste processing in Enrekang Regency are still managed subsistently and commercially. This production mode plays an important role in helping to increase output per unit of labor through innovation and technology [4-6]. Therefore, it aims to analyze the economic value of the application of biogas technology based on dairy farming. 


\section{METHODOLOGY}

This research was conducted from October 2020 to December 2020 in Enrekang Regency. This location was chosen deliberately because Cendana District is one of the centers for developing dairy cows and has the largest population in Enrekang Regency and has the opportunity to utilize biogas at household scale. This study uses data sources consisting of primary and secondary data. Primary data obtained through observation, interviews with farmers and the government using a questionnaire. Secondary data were obtained from the Center for the Assessment of the Process and Energy Industry, Central Statistics Agency, Statistical Data of the Enrekang District Animal Husbandry Office, research reports and publications from journals. Data were analyzed with quantitative data using an economic value approach from the application of biogas technology.

\section{RESULTS AND DISCUSSION}

\subsection{Biogas Production in Enrekang District}

Biogas development in Enrekang, South Sulawesi, is one of Indonesia's domestic biogas programs (BIRU) which was started in 2010. Biogas is a renewable energy source capable of contributing to the effort to meet fuel needs. The raw materials for this energy source are non-fossil materials, generally waste or livestock manure whose production depends on the availability of grass and grass will always be available [7].

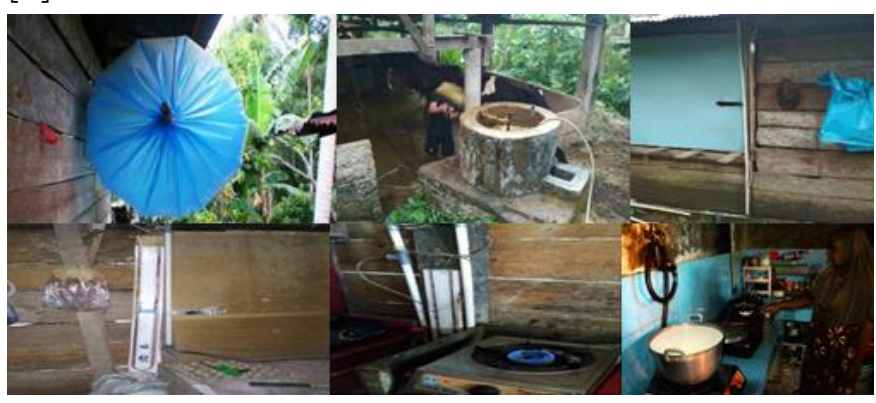

Figure 1. Biogas From Dairy Cow
Figure 1 shows that the biogas installation process begins by making a digester/reactor area, temporarily accommodating dirt, providing four stirrers, a channel to the reactor, installing a gas pressure gauge and a biogas stove. The size of the reactor is adjusted to the amount of biogas potential and the location of the reactor. If the potential is large and it is located in a district, the reactor that is being built may have a minimum capacity of 20-30 cubic meters. Utilization of biogas from livestock feces is an effort to build a habit of using alternative and renewable energy sources.

The use of biogas from livestock manure has the following advantages: 1 ). Save on budget expenditures in purchasing Liquefied Petroleum Gas and kerosene. 2). Using biogas as fuel for cooking dangke, which is available at any time. 3) Making fertilizer from biogas waste which is very useful as a source of nutrition for plants. This type of fertilizer also contains less pathogenic bacteria. The results of this study are supported [8] - [12], Biogas is useful as an alternative energy source, plant growth is better after being fertilized by biogas waste due to pest attacks and fewer weeds. fermented manure and ecosystem balance to ensure sustainable agricultural activities in processing livestock waste, to improve environmental sanitation, and address household economic costs.

\subsection{Economic Value of Biogas Technology Applications}

The application of biogas technology in Enrekang Regency which has dairy farms can provide economic benefits if the proper design is carried out from a technical and operational perspective. Currently, the use of biogas as alternative energy has not been able to fully substitute conventional household energy. However, the use of biogas can actually result in nominal savings in the overall energy cost structure 
[13]. The economic value of the use of biogas 1 . technology in Enrekang Regency can be seen in Table

Table 1. Economic Values of The Application of Biogas Technology With Kerosene, LPG And Firewood

\begin{tabular}{ccrrrr}
\hline District & $\begin{array}{c}\text { Gas } \\
\text { production } \\
\text { potential } \\
\left(\mathrm{m}^{3} / \text { day }\right)\end{array}$ & $\begin{array}{c}\text { Gas } \\
\text { production } \\
\text { potential } \\
\left(\mathrm{m}^{3} / \text { year }\right)\end{array}$ & $\begin{array}{c}\text { Equivalent } \\
\text { to kerosene } \\
\text { (liters) }\end{array}$ & $\begin{array}{c}\text { Equivalent to } \\
\text { Liquefied } \\
\text { Petroleum } \\
\text { Gas (kg) }\end{array}$ & $\begin{array}{c}\text { Economic value } \\
\text { of biogas } \\
\text { applications } \\
\text { (IDR) }\end{array}$ \\
\hline Maiwa & 2 & 730 & 453 & 336 & 2.238 .667 \\
Bungin & 12 & 4.380 & 2.716 & 2.015 & 3.432 .000 \\
Enrekang & 200 & 73.000 & 45.260 & 33.580 & 223.866 .667 \\
Cendana & 828 & 302.220 & 187.376 & 139.021 & 926.808 .000 \\
Buntu Batu & 116 & 42.340 & 26.251 & 19.476 & 129.842 .667 \\
Baraka & 64 & 23.360 & 14.483 & 10.746 & 71.637 .333 \\
Anggeraja & 284 & 103.660 & 64.269 & 47.684 & 317.890 .667 \\
Malua & 20 & 7.300 & 4.526 & 3.358 & 22.386 .667 \\
Alla & 164 & 59.860 & 37.113 & 27.536 & 183.570 .667 \\
Curio & 46 & 16.790 & 10.410 & 7.723 & 51.489 .333 \\
Masalle & 138 & 50.370 & 31.229 & 23.170 & 154.468 .000 \\
Baroko & 12 & 4.380 & 2.716 & 2.015 & 13.432 .000 \\
\hline
\end{tabular}

Source: Primary data that has been processed, 2020.

Table 1 shows that the number of dairy cows in Enrekang Regency in 2020 was 943 heads. The potential for biogas that can be produced is 1.886 $\mathrm{m} 3 /$ day or $688.390 \mathrm{~m} 3 /$ year. The amount of biogas is equivalent to 426.802 liters of kerosene, so that if the price of kerosene per liter is IDR 11.000 , the funds that can be saved per year will be IDR 4.694.822.000. In addition, the economic value that can be saved from the application of biogas technology if calculated with the equivalent value of $3 \mathrm{~kg}$ Liquefied Petroleum Gas is IDR 2.111.062.667/year. So that the application of biogas energy for rural communities who own livestock is the right solution to reduce fuel consumption from fossil fuels, in addition to that, 25 $\mathrm{kg}$ of fresh cow dung can produce $10 \mathrm{~kg}$ of solid organic fertilizer from biogas digester by-products which can be used for agricultural business or household vegetable garden. This is supported by [14] - [15]. Cow manure is the most efficient use as a biogas producer because every 10-25 kg of cow dung per day can produce $2 \mathrm{~m} 3$ of biogas. . Where the energy contained in $1 \mathrm{~m} 3$ of biogas is $4.7 \mathrm{kWh}$ or can be used as 60 - 100 watts of lighting for 6 hours. $1 \mathrm{~m} 3$ of biogas can be used equivalent to 0.62 liters of kerosene and $0.46 \mathrm{~kg}$ of Liquefied Petroleum Gas.

Solid waste processing can contribute to IDR $1,800,000$ to farmers. The income received by breeders generated by breeders is greater than the net income from selling cattle. The sales income of organic fertilizer is IDR $3,344,166 /$ month by processing $2.500 \mathrm{~kg} / \mathrm{month}$ or the equivalent of 30 tons in a year, cow dung is sold in $5 \mathrm{~kg}$ and $10 \mathrm{~kg}$ packages assuming it is acceptable to the market [16] [17]. This is supported by the opinion of [18], which states that alternative biogas energy has a very real effect on household expenditure savings. According to [19]. the use of dairy cow dung for biogas installations provides benefits not only for household 
needs but for productive economic and health activities. Productive economic activities include the growth of agro-industries made from milk raw, such as caramel, milk crackers, pasteurized milk, milk tofu. One of the successes that have an impact on people's income and economic improvement.

\section{CONCLUSION}

The economic value that can be saved from the application of biogas technology is IDR 2.111.062.667/year. The economic value of biogas as an alternative fuel commonly used by households appears to be relatively large. Therefore, the economic benefits of biogas are not only obtained from its ability to produce fuel substitutes, but also its ability to produce a by-product in the form of manure. Therefore, the economic benefits of biogas are not only obtained from its ability to produce fuel substitutes, but also its ability to produce a by-product in the form of manure.

\section{REFERENCES}

[1]. Rachmawati, R. A., Wahjoedi \& Widjaja, S. U. M. 2017. Meaning of Biogas as a Household Energy Source. Jurnal Pendidikan: Teori, Penelitian, dan Pengembangan Volume: 2 Nomor: 4 Bulan April Tahun 2017: 487-493

[2]. Mulyati, M. 2018. Biogas Technoeconomic Analysis of Water Hyacinth with Cow Manure Stater. Jurnal Energi dan Teknologi Manufaktur. Vol. 01, No. 02, Bulan Desember Tahun 2018: 39 - 44.

[3]. Irsayad, F dan Yanti, D. 2016. TechnoEconomic Evaluation of Household Scale Biogas Utilization as Environmentally Friendly Alternative Energy Source. Jurnal Teknologi Pertanian Andalas Vol. 20, No.2 September 2016. ISSN 1410-1920 : 73-79.
[4]. Aisyah R. S, Salman, D. Siregar, A. R and Baba, S. 2020. Potential of Biogas Production As Renewable Energy In Smallholder Dairy Farming in Enrekang District, South Sulawesi. IOP Conference Series: Earth and Environmental Science 473 (2020) 012114. IOP Publishing doi:10.1088/17551315/473/1/012114.

[5]. Salman, D. Aisyah R. S. Siregar, A. R and Baba, S. 2020. Coexistence mode of production based dairy cow supporting farming in producing biogas as renewable energy resources. IOP Conf. Series: Earth and Environmental Science 473 (2020) $012113 \quad$ IOP Publishing doi:10.1088/1755-1315/473/1/012113

[6]. Aisyah R. S, Salman, D. Siregar, A. R and Baba, S. 2020. Modernizing Dairy Farm: A Production Mode Analysis. International Journal on Advanced Science, Engineering and Information Technology Vol.10 (2020) No. 2: 775-781. ISSN: 2088-5334

[7]. Haryati, T. 2006. Biogas: Animal Husbandry Waste which is a Source of Alternative Energy. Wartazoa. Vol 16 (3):160-169.

[8]. Minde, G.P., S.S. Magdum, and V. Kalyanraman. 2013. Biogas As a Sustainable Alternative For Current Energy Need Of India. Journal Sust. Energy Environ. 4: 1210132.

[9]. Dianawati, M dan Mulijanti, S. T. 2015. Opportunities of Biogas Development in Dairy Cattle Center Areas. Jurnal Litbang Pertanian . Vol. 34 No. 3 September 2015: 125-134

[10]. Syam, J., Salman, D., Hasan, S., Ismartoyo \& Sirajuddin, S. N. 2019. Adaptive Strategies Of Livestock Waste Processing Technology To Vulnerability Availability Of Animal Feed Adaptive Strategies Of Livestock Waste Processing Technology To Vulnerability Availability Of Animal Feed. GIESED 2018 IOP Conf. Series: Earth and Environmental Science 235 (2019) 012069. 
[11]. Mappa, N., Salman, D., Siregar, A. R \& Arsyad, M. 2018. Mapping Of Land Tenure Institution Rotating Patterns In The Highlands. IOP Conf. Series: Earth and Environmental Science 157 (2018) 012072. doi :10.1088/1755$1315 / 157 / 1 / 012072$

[12]. Kasim, K. Salman, D. Siregar, A. R. Nadja, R. A \& Ahmad, A. 2019. Vulnerability and Adaptive Strategies On Duck Breeder In Pinrang District, Indonesia. IOP Conference Series: Earth and Environmental Science 235 (2019).

[13]. Daud, A. R. 2011. Economic Value of Biogas Benefits in Dairy Farming Household: Survey in Haurngombong Village, Pamulihan District, Sumedang Regency. Sosiohumaniora, Volume 13, No. 3, November $2011: 243-250$

[14]. Saputri, Y. F., Yuwono, T., Mahmudsyah, S. 2014. Utilization of cow manure for fuel of 80 $\mathrm{Kw}$ Biogas Plt in Baba Village and Ngajum District Malang. Jurnal Teknik Pomits Vol. 1, No. 1, (2014) 1-6

[15]. Monika, F. 2013. Analysis of Economic Feasibility and Capacity of Biodigester Model Fix Dome Plant: Case Study of Biodigester in Botokenceng, Yogyakarta. Jurnal Ilmiah Semesta Teknika VOL. 16, NO. 2, 108-116, NOVEMBER 2013: 108-116.

[16]. Perwitasari F. D. dan Yuliananda D. 2016. A Study on Cattle Livestock Waste as an Economic Source of Cattle Farming Business Income in Dukuhbadag Village, Cibingbin District, Kuningan Regency. Prosiding Seminar Nasional Peternakan Berkelanjutan 8. Hal 177 183

[17]. Kasworo, A., Izzati, M \& Kismartini. 2013. Animal Manure Recycling as an Effort

[18]. to Support Sustainable Beef Cattle Farming in Jogonayan Village, Ngablak District, Magelang Regency. Prosiding Seminar Nasional Pengelolaan Sumberdaya Alam dan Lingkungan. Hal 306 - 311.
[19]. Damanik. L.H, Husodo A.H \& Gunawan, T. 2014. Utilization of Cattle Feces as Alternative Energy for Household Biogas and Its Impact on the Environment. Jurnal Teknosains vol 4 (1). Hal $54-63$

[20]. Hermawati, N. 2012. Economic, Social, and Environmental Impact Analysis of Dairy Cattle Waste Utilization: A Case Study in Haurngombong Village, Pamulihan District, Sumedang Regency, West Java. Skripsi. Departemen Ekonomi Sumberdaya dan Lingkungan, Fakultas Ekonomi dan Manajemen, Institut Pertanian Bogor.

\section{Cite this article as :}

St. Aisyah R, Asriyanti Syarif, "Economic Value from Biogas Technology Application Based on Dairy Cow Farming", International Journal of Scientific Research in Science and Technology (IJSRST), Online ISSN : 2395-602X, Print ISSN : 2395-6011, Volume 8 Issue 1, pp. 78-82, January-February 2021. Available at doi : https://doi.org/10.32628/IJSRST21818 Journal URL : http://ijsrst.com/IJSRST21818 